EPRA International Journal of Economic and Business Review-Peer Reviewed Journal

Volume - 9, Issue - 4, April 2021 | e-ISSN: 2347 - 9671| p- ISSN: 2349 - 0187

\title{
A CONCEPTUAL STUDY OF JOB OPPORTUNITY IN JHARKAND
}

\begin{tabular}{|c|c|}
\hline Dr.Sanjay Prasad & ${ }^{1}$ Asst.Professor, St.Xavier's College, Ranchi \\
\hline Srinath Koley & \\
\hline & ${ }^{2}$ Reseach Scholar, St.Xavier's College, Ranchi \\
\hline
\end{tabular}

\section{ABSTRACT}

DOI No: $10.36713 /$ epra6682
Article DOI URL: https://doi.org/10.36713/epra6682

Job turnover has been a longstanding concern to academic researchers whereby numerous researchers have resulted in the classification of factors that cause turnover intentions among employees. Indian context has been well explored, but the literature remain scant on the issue in the context of Indian countries especially Libya. This study is an attempt to address the gap in literature and aimed at determining the relationship amid training, job satisfaction and alternative jobs on employee turnover in the Libyan oil sector. The correlation findings revealed that training has insignificant relationship with job turnover, whereas job satisfaction and alternative job are positively related to job turnover. Finally, recombination are made for future research and implications for Sail, Bhel and Many more oil companies to improve their practices. Performance. This discussion in literature provides the impetus to examine the relationship between training, job satisfaction, and job opportunity with job turnover in private Sectors.

KEYWORDS: - job satisfaction, Sail, Bhel, turnover.

\section{INTRODUCTION}

Job satisfaction is the most widely studied work-related attitudes in the fields of organizational psychology, and organizational behaviour. Copious literature discussing the relationship between provision of training, job satisfaction and turnover is based on the human capital theory utilizing quantitative approaches abundance of empirically the linkages between training and job turnover. Regardless of the literature, the existing empirical researches suggest that the relationship is not straightforward; with mixed findings on the relationship between training and job turnover. Further to that, here are many fields and career opportunities that unlock after pursuing a course in computer accounting. Applicants seeking a job in computer accounting can pursue different short-term courses offered by various institutes in India. The best courses offered in Computer accounts include the diploma courses at different levels after pursuing graduation.

This article includes all the information related to a career in computer accounting such as the roles of a computer accountant, the syllabus of course, how to become a computer accountant, curriculum, skills required, list of courses offered, recruiting companies, books, and study material, etc. 
Read the complete article to know more about pursuing a career in Computer Accounting.

\section{Training}

Training and development practices constitute one of the most important ways to assist personnel in gaining new knowledge and skills required to adhere to competitive standards. Studies have suggested that human resource practices such as extensive training would create a sense of organizational support. Providing career development opportunities via training and development of employees is increasingly recognized as an important aspect of best human resource management practices.

\section{Job Turnover}

Job turnover occurs when an employee leaves a specific job or organization permanently and his/her services are no longer available. As a result of job turnover, new employees must be tired. Recruitment, selection, hiring, placement, training and separation are among the direct costs related to job turnover. The actual turnover is more difficult to predict than turnover intention. Job turnover can be predicted by turnover intention.

\section{Job Satisfaction}

Job satisfaction as one of the most researched work-related variables has been shown to negatively influence undesirable employee behaviour, such as absenteeism and turnover intentions .Managers struggled to understand how they could minimize turnover and this generally led them back to the need to understand their employee's perceptions of satisfaction.

The relationship between variables. Employees exhibit the intention to leave an organization when training is inadequate for a job many researchers found a negative relationship between training and turnover intention. However, other results did not confirm past researches, but showed contrary findings. People who were more satisfied with their access to training programs were more likely to leave. Also, there is a significant negative correlation between turnover intentions and job satisfaction. Other study found positive relationship between job satisfaction and turnover intention. Other kind of results which found that job satisfaction does not have any significant relationship with turnover intention. Also, significant positive correlation between perceived alternative job opportunities and turnover intention.

The conceptual framework contains the training and, satisfaction and alternative employee opportunity as independent variables, while job turnover is dependent variable.

\section{Keys Massage}

1. Influential trends that will shape the jobs of the future include: global integration; technological innovation; an ageing population; collaboration and cross disciplinarily; increased participation of women in the labour force; continued economic shift to Asia, scarcity of natural resources; migration.

2. The key sectors covered where these trends will have impact include: health and social assistance, construction, technology and big data, manufacturing, hospitality and tourism, creative industries.

3. The workforce is changing, both with the continuing youth bulge and an ageing population. Accompanying that change is a looming skills mismatch, where employers and employees lack the skills necessary for today's jobs.

4. Emerging sectors and technological innovation are changing the global workforce landscape. The adaptability of institutions, the private sector, employees and policy makers will determine their success.

5. Collaborative efforts among actors are necessary to ensure that the future generation can meet and overcome unemployment and skills gaps.

\section{Educational / Training / Job opportunities After 1oth \& 12th}

1. Career choice - one of the most important milestones in an individual's life involves self-analysis, critical thinking and finally decision making.

2. The choice of the career is influenced by views of your parents, friends, relatives, teachers and the media. Today with a wider choice and an ever increasing competition, you need to plan your career wisely and at the earliest.

3. While choosing a stream after 10th, a training course or a career you should know your abilities, interests, aptitudes and personality. Besides these you should gather information regarding different career options, the eligibility criteria, the premier institutions/universities, and other criteria of selection and the market demands.

4. The present project undertaken by Education Department of Jharkhand on different companies.

5. Educational and vocational courses available in Delhi and the Job opportunities through competitive examination after 10th and 12th aims at giving you the much needed information.

6. Hoping that it would help you in understanding what each course and a career entails and help you introspect and analyse the required abilities to be successful, happy and content in the course/career you choose. 


\section{Career in Computer Accounting: Role}

A computer accountant is responsible to prepare the financial statements of a business firm or company in a computerized format. The computer accountants are responsible to enter the financial data in the book of accounts on a daily basis. The accounting data can be recorded in various accounting software by using computers.

1. The qualification of a computer accountant varies as per the nature of the accounting job. An accountant is in charge of keeping the record of a company's profit and loss data in a comprehensive way. The financial records should be maintained in such a way that it helps the organization to make improved decisions. Accountants play various roles for the proper maintenance of books of accounts, some roles of a computer accountant are provided below:

2. Financial Data Management: One of the major responsibilities of an accountant is to collect and maintain the organization's financial information. They make sure that the storage of financial accounts is done as per the legal compliances and approved procedures.

3. Financial Data Analysis: In case of any financial misdeeds or differences, the computer accountants analyse all the financial data to resolve these issues. They can also suggest some competent resources and events for specific financial deficiencies or problems.

4. Financial Compliance Auditing: They are also responsible to follow all the legal compliances related to financial reporting deadlines. In accounts, the authorities have specified quarterly, monthly, and annual financial reporting systems, which should be met on time to avoid penalties. If the financial compliance is not met on time, then there might be some tax consequences.

\section{Career Scope}

There are immense job opportunities are available in these fields. After holding a degree in this field you can take up for a job in both private and government sectors. Professionally you can also opt teaching jobs in colleges and universities.

You can find jobs according to your educational background and working experience. You can work in different fields such as different government and private organizations, business banking sector, colleges, universities, economic companies, etc.

\section{What Job Title Might I Have? Here we have listed some job titles of these fields \\ $\checkmark$ Accountant \\ $\checkmark$ Tax Policy Analyst \\ $\checkmark$ Financial Analyst \\ $\checkmark$ Internal Auditors \\ $\checkmark$ External Auditors \\ $\checkmark$ Employment Tax Specialist \\ $\checkmark$ Personal Finance Consultant}

Role of a Tax Accountant

$\checkmark$ Preparing and submitting accounts and tax returns.

$\checkmark$ Advising about business plans, investment opportunities, etc.

$\checkmark$ Assisting clients with financial and income tax statements.

$\checkmark$ To develop or plan strategy to minimize the income tax.

\section{Role of an Auditor}

$\checkmark$ To give the true view of the profit or loss of the company.

$\checkmark$ Test documentation and supporting account balance.

$\checkmark$ To ask about the management and others to develop an understanding of the company.

$\checkmark$ Prepare audit reports and shows result to the authorities.

\section{Methodology}

This study aims to analyse the status of Financial Inclusion through Self Help groups (SHGs) in Jharkhand. Secondary data will be used from the sources like,

1. Age of sample worker groups of Jharkhand in year

\section{Analysis and Interpretation}

AGE OF SAMPL WORKER GROUPS (in Years)

\begin{tabular}{|c|c|c|c|}
\hline \multirow{2}{*}{ AGE OF GROUP } & NUMBER OF RESPONDENTS & \multirow{2}{*}{ TOTAL } \\
\cline { 2 - 4 } & OFFICE BEARERS & MEMBERS & \\
\hline $18-25$ Years & $33(21.29 \%)$ & $39(25.16 \%)$ & $72(23.23 \%)$ \\
\hline $25-33$ Years & $88(56.77 \%)$ & $91(58.71 \%)$ & $179(57.74 \%)$ \\
\hline Above 33 Years & $34(21.94 \%)$ & $25(16.13 \%)$ & $59(19.03 \%)$ \\
\hline TOTAL & $155(100.00 \%)$ & $155(100.00 \%)$ & $310(100.00 \%)$ \\
\hline
\end{tabular}

Sources: Yojana

It is evident that indicated only those worker groups which had completed at least 18-25 years of savings and credit linkage was selected for the study. A majority (76.77\%) of the worker groups selected in 
the sample were functioning for more than 25-35 years. The rest are functioning for less than 33 years $(23.23 \%)$. Majority of the groups were 33 years old because, in Jharkhand city worker groups were started from 2011 that's why most of the worker group's crossed 33 years.

\section{CONCLUSION}

Employee satisfaction is the terminology used to describe whether employees are happy and comfortable and accomplishing their desires and needs at work. Employee satisfaction can also be based on the effect of an individual's experience of work, or the quality of their working life. Employee satisfaction can be well understood in terms of its connection with some key factors, such as wellbeing, stress at work, control at work, working condition etc. employee satisfaction is based on how the organization treats them, effective employee satisfaction for individuals reflects from the emotional feeling they have about their job.

\section{REFERENCES \\ Journals}

1. International Journal of Management (IJM), ISSN 0976 - 6502(Print), ISSN 0976 - 6510(Online), Volume 6, Issue 2, February (2015), pp. 31-42 -31

2. DOI: $10.9790 / 487 X-18241724$ www.iosrjournals.org 2

3. Volume ISBN: 0-226-15540-4 Volume URL: http://www.nber.org/books/dool03-1 Conference Date: March 28-31, 2001 Publication Date: January 2003

\section{BOOKS}

1. Systematic Approach to Income Tax, ST and VAT by CA. Girish Ahuja and Dr. Ravi Gupta

2. Students Guide to Income Tax by Dr. Vinod K Singhania and Dr. Monica Singhania

3. Students Handbook on Income Tax, VAT and ST by T.N. Manoharan and G R Hari

4. Principles of Auditing \& Other Assurance Services by Ray Whittington

\section{NEWS PAPER}

The Hindu 